Oksana Havrosh, Nataliia Rebryk. Artistic nonconformism of Transcarpathia of 1960-1980...

DOI https://doi.org/10.30525/978-9934-26-065-0-8

Oksana Havrosh,
Candidate of Art History, Associate Professor of Culture and Socio-Humanitarian Disciplines of Transcarpathian Academy of Arts ORCID ID: 0000-0002-9456-1460

Nataliia Rebryk,

Candidate of Phylological Sciences Associate Professor of Culture and Socio-Humanitarian Disciplines Pro-Rector of Transcarpathian Academy of Arts ORCID ID: 0000-0002-5133-6642

\title{
ARTISTIC NONCONFORMISM OF TRANSCARPATHIA OF 1960-1980: INTELLECTUAL BACKGROUND AND PERSONALITIES
}

\begin{abstract}
The article attempts an artistic and aesthetic analysis of modern art of Transcarpathia in the 1960s - 1980s, defined as nonconformism and underground, arguing that artists really contradicted the established philosophical, ethical, aesthetic codes of society and directed their art to self-expression. Having analyzed art processes in Transcarpathia during the Khrushchev «Thaw» and the 1980s, the authors have outlined the preconditions of manifestation and dissemination of ideas of nonconformism in the artistic environment of Transcarpathia and in the works of P. Bedzir, E. Kremnytska and F. Seman. The article conveys the idea that the artistic underground environment of Transcarpathia is a definite and courageous response of creative personalities to the reactionary social phenomena of the 1960s - 1980s, and the general analysis of alternative painting genre of Transcarpathia in the 1970s - 1980s reveals a wide range of influences both of world art trends and features of ethno-culture of Transcarpathia. The works of F. Manailo, E. Kremnytska, P. Bedzir, F. Seman, Y. Cherni were distinguished by their individual technique of creating compositions, the search for new methods of shaping, which rather corresponded to the state of enlightenment. Unlike artistic manifestations in the spirit of socialist realism,
\end{abstract}


such creative experiments were associated with social freedom. Such processes of creative digression significantly influenced the formation of a new paradigm that emerged in the early 1990s.

Keywords: artistic creativity, self-expression, underground, ideology, social realism, «samvydav», opposition, European modernism.

Problem statement. The experience of 30 years of Transcarpathian artists being in the conditions of socialist-realist Soviet art led to conformism with the dominant ideology, which also affected the works of art. Rationalization of the form under the influence of narrative-poster and moralizing plot flooded the works of the vast majority of Transcarpathian artists. The reflection of meaningless rituals of the ideological system and its achievements determined the official order in artistic practice, which was the most common way for artists to express themselves in the 1970s.

Prejudiced attitude of members, deliberate refusals to present works at regional exhibitions, long-term refusals to publish, official condemnation of «wrong» views on the development of art in periodicals, «analysis and elaboration» at various meetings with official condemnation of «indecent behavior» affected the spirit of creativity neither for writers nor artists, who did not fit into the system. Despite the ideological conditionality and normative nature of Transcarpathian literature and painting, in the 1960s - 1980s regional art underwent the processes of actualization of creativity based on the paradigm of informal art. Thus, the works of F. Kryvin, P. Skunts, or later D. Kremen, the artistic compositions of P. Bedzir, E. Kremnytska, and F. Seman of the late 1960s - 1970s vividly illustrate the principles of nonconformism in contrast to the academic realism of the Ukrainian model, which imbued Transcarpathian art in those days. The artists' disillusionment of the ideas of socialist realism became a position of effective opposition, which turned into years of non-recognition and disregard for them. Despite this, the authors continued the search for individual artistic language, sensuality of painting and sharp thematic subjectivity.

In the works of F. Kryvin, P. Skunts, D. Kremen, P. Bedzir, E. Kremnytska and F. Seman there is a restoration of conceptual ties with European modernism of the first half of the XX century and current trends in European art between 1960s and 1980s. Nonconformist artists solved the problem of artistic search and 
embodiment of individual views with words, paintings and graphics. At the same time, the synthesis of the latest artistic language with the interpretation of the forms of folk art of Transcarpathia played an important role in their work. Here we see the continuation of the search, begun by artists of the sixties and the formation of the foundations of the neo-folk movement in the mid-1980s, as well as the creative search for representatives of the «new wave».

Analysis of recent publications and researches. The collapse of the USSR and Ukraine's independence opened up new opportunities for studying the work of Transcarpathian artists. The liberation of theoretical thought allowed to look more objectively at the works of famous artists. Publications attempted to view artistic processes not as a selection of official events, but as a set of ideas that in certain historical periods determined the development of cultural environment. The change of the general cultural paradigm allowed to include in the all-Ukrainian context the names of those Transcarpathian artists whose work was silenced or was poorly covered in Soviet times. Among the researchers who study the work of representatives of the underground and nonconformism in Transcarpathia, there are names of D. Horbachov, B. Lobanovskyi, O. Petrova, G. Skliyarenko, O. SydorHibelinda, H. Vysheslavskyi, I. Dziuba, Y. Kovaliv, V. Bazylevskyi, L. Starovoit, V. Boichenko, E. Baran, V. Korotych, V. Shuliyar, A. Maliarov, I. Bereza, T. Kremen, M. Syrokhman, B. Shumylovych, I. Nebesnyk and others.

Purpose of the article is to analyze the artistic processes in Transcarpathia during the Khrushchev «Thaw» and the 1980s, the preconditions of manifestation and dissemination of ideas of nonconformism in the artistic environment of Transcarpathia, particularly in the works of P. Bedzir, E. Kremnytska and F. Seman.

Presentation of the main material. The situation at the turn of the 1950s and 1960s in Ukrainian art was marked by new shifts: the easing of ideological pressure after the XX congress of the CPSU. The «breakthrough of the sixties» in the period of political thaw contrasted the ephemeral ideals of internationalismcollectivism with the priorities of personal identification and self-worth $[6,16]$. In the history of Transcarpathian art of this time we will not find examples of sharp opposition and defense of the national position, which were demonstrated by artists from Lviv or Kyiv. In the works of Transcarpathian artists, the spiritual insight and rethinking of the experience of previous generations was manifested in the humanity of the plots and a certain confessional intonation of the works. 
The depletion of the ideas of social-realism contributed to the search for new forms in art, which primarily manifested itself in the revival of national priorities.

Young artists took an active position in the reassessment of spiritual and moral values. In 1958 the first regional exhibition of young artists of Transcarpathia took place, which presented 130 works of painting, graphics and sculpture. Among the names that appear in the lists of participants are future famous Transcarpathian artists, namely V. Zvenyhorodskyi, Y. Hertz, M. Sapatiuk, A. Shepa, P. Itiaksov, P. Bedzir, E. Kremnytska, M. Bilanina, N. Tolstaia, M. Medvetskyi, M. Ilku. Most of them were graduates of the School of Decorative and Applied Arts and studied with the founders of the Transcarpathian Art School - A. Erdeli, Y. Bokshai, F. Manailo.

However, the process of liberalization did not affect the weakening of control over the ideological and thematic content of the works. Critical remarks were made to A. Erdeli's student - Volodymyr Mykyta, whose works were dominated by dark blue-green tones, which were far from a realistic interpretation of nature. F. Seman's work was also sharply criticized - a project for the mosaic «Jazz», called «vicious in ideological content», which «promotes rotten bourgeois culture», music and dance in the style of «boogie-woogie» and «rock and roll». With a general positive assessment of the work of young artists, it was noted that their works are detached from life and ideologically meaningless [9, 27].

The mid-1960s were marked by a growing political and ideological reaction to attempts to reform the totalitarian system. This was preceded by the removal from power of Khrushchev at the plenum of the Central Committee of the CPSU in October 1964. The new leadership, led by L. Brezhniev and M. Suslov, quickly suspended all reforms of the command-and-control system. Cultural and artistic life was again subjected to maximum standardization, and dissent, religious activity, and the defense of the national idea were actively persecuted and repressed.

In the late 1960s a wave of persecution aimed at affirming the spirit of imprisonment and national doom began in Transcarpathia. Among the most significant cases - «re-education» by administrative measures in 1968 I. Chendei was noted for the collection «March Snow», at the same time regime saw the danger in the poem «Crucifixion» by P. Skunts [10]. In 1971, F. Kryvin was punished for several years for the book «Imitation of the Theater» and deprived of the opportunity to publish. In 1974 D. Kremen's poetic works were subjected to public slander. 
Artists managed to avoid the educational repression suffered by some writers. In an atmosphere of anticipation, artistic life took place according to a clearly defined plan. It is significant that the Czechoslovak events of $1968 \mathrm{did}$ not affect the holding of international exchange exhibitions, which confirms the opinion about the reliability of Transcarpathian artists. The main creative research was focused on the revival of tradition, in particular, ethnic imagery. Social and everyday themes were actively developed in painting, where the main characters were ordinary peasants, in contrast to industrial themes, which at that time were common in Ukrainian painting [2, 74].

Since 1965, Transcarpathians have been taking part in exhibitions in Kyiv every 5 years. The expositions of «artistic five-year plans», as a rule, were timed to the date of reunification of Transcarpathia with Soviet Ukraine and demonstrated the best achievements of fine and decorative arts of the region during this time. From the analytical article of the art critic G. Ostrovsky we learn, that at the exhibition in 1965 a generation of thirty-year-olds was widely represented, namely V. Mykyta, A. Shepa, E. and M. Medvetski, P. Balla, P. Bedzir, E. Kremnytska, Y. Bokshai Jr. and others [13, 20-21]. Despite the official ideological «barometer», the researcher noted in their works the continuation of the traditions of the luminaries - A. Erdeli, Y. Bokshai and F. Manailo. In some ways, the critic defended the old artistic principles of the Transcarpathian school of painting, but pointed out that the paintings of the younger generation are more focused on external effects, in contrast to the works of luminaries, who always agreed with the time and spirit of their people.

The scale of republican exhibitions gradually grew. In the summer of 1970, a wide retrospective jubilee exposition of Transcarpathians in Kyiv «25 years of Soviet Transcarpathia» took place. From the report of A. Kashshay - the chairman of the regional Union of artists, we learn about the unprecedented scale of the exhibition, which presented the work of 58 artists with 340 works [7, 7]. As usual, considering the scale of exhibition activities, we note a formal approach to their organization. This trend clearly reflects the reorientation of aesthetic aspects to the «current» problems of Soviet art in the late 1960s. It is possible that the experience of permanent struggle against the manifestations of formalism in the works of the older generation of Transcarpathian artists was noticeable. The end of the 1960s was the period of the final stratification of art into informal and official, 
which, in fact, was the presentation of these events. For many artists, Kyiv thematic exhibitions were a good opportunity to legalize their creative work at the national level and to provide an ideologically protected existence within their own creative pursuits.

Attempts by artists to create based on individual experience and worldview were blocked by regular political party guidelines. Artists, who did not fit into the «updated» format of socialist realism, were forced to find themselves in a situation of semi-officiality or complete informality, which meant tight isolation in the overall artistic process. As a rule, any manifestation of one's own language of expression, the search for the author's creative manner were declared harmful from an ideological point of view. During these years, the works of informal artists appeared in Transcarpathian painting, declaring the original knowledge and disclosure of the meaning of human life and the depth of personality. The movement of nonconformism in the paintings of Transcarpathia became the first step towards the renewal of art, actualizing the individual search in a general historical Ukrainian artistic process.

During the 1970s, the number of thematic paintings in Transcarpathian art grew rapidly. The external bombast of artistic images in the compositions of the 1970s contrasted sharply with the content of post-war works, which were characterized by a rich internal reality. It seems that the theme successfully chosen by the artist (and sometimes only the title) determined the success of the work. This trend explains the superficiality of the content of the compositions and, accordingly, professional miscalculations. «Photographisity» and «illustrativeness» - a list of questionable innovations in painting in the 1970s.

In the Transcarpathian artistic space, the period of «quiet totalitarianism» was characterized by already formed stereotypical thinking, which vividly illustrates the «buffoonery» thematic paintings. Soviet mythologisms were firmly rooted in the painting of Transcarpathia, which testified to the reduction of characters. However, despite the mass artistic gratification of the system, there were artists in the Uzhhorod community who developed contrary to official art. In the conditions of ideological obedience of local artists, the works of F. Seman, P. Bedzir and L. Kremnytska, whose names are today among the first in the lists of participants of the nonconformist movement in Ukraine, were perceived as controversial to the general situation since the late 1960s. 
The alternative movement of the 1960s - 1980s, defined in modern art history as underground, nonconformism, or informal art, was based on the priority principles of one's own views contrary to Soviet canons. If in Kyiv and Lviv the grouping around active reformers took place in the Clubs of Creative Youth in the early 1960s. ("Contemporary» and «Snowdrop»), in Uzhgorod, these processes intensified only in the early 1970s, a period, which famous Transcarpathian poet, winner of the T. Shevchenko's National Prize Petro Midianka called «years of black Malanchuk's reaction» $[1,31]$. As a rule, Uzhhorod meetings were held in the format of communication and rather resembled the friendly gatherings of artistic bohemia. This is confirmed by their location - the restaurant «Verkhovyna» and the format - a casual conversation over coffee. Here is how the Ukrainian poet Dmytro Kremin remembers these times: «All our meetings of poetic and artistic bohemia in restaurants were in sight of the unblinking eyes of a cobra! - the most intelligent special services officers... There were three times as many secret workers as the population itself... But the seventies were not quite cannibalistic. And the system then played with talents. They flirted with us, as in the days of the Roman or Russian Empire» [1, 70].

With their openness and relatively easy access, Uzhhorod meetings differed significantly from those in Kyiv or Lviv, which in the period 1970-1980 switched to the format of «closed» in selected workshops. Among the like-minded people in Uzhhorod, the central figures were P. Bedzir and F. Seman. The «leader» of the informals, together with his wife L. Kremnytska and his colleague F. Seman, whom the official structures called the «avant-garde cube», quickly became an «alternative spiritual center» in Uzhhorod. Gathering in the «Verkhovyna» restaurant, they philosophized and discussed the works of banned modernists, whose lives they learned from Hungarian publications. Attempts at free discussion united young students around artists. "There was no organized abstractionist group. We (author - F. Seman, P. Bedzir, E. Kremnytska) were each in himself. Students came to us because they always react to something new. Now famous writers Dmytro Kremin, Desiderii Matola, Dmytro Keshelia came. Artists from Kyiv, Lviv, Riga, Leningrad came, looking for impulse, mutual understanding, because in their souls they all denied the Soviet reality» $[1,27]$.

For young people who were brought up behind the «Iron Curtain», bright creative personalities became an example of not only bohemian life, but also 
a reference point for world artistic processes and philosophical models. A kind of private «free academy of arts», created by Bedzir, became an accumulator of free art in Uzhhorod. Despite his activity, the artist did not consider himself a fighter. He called his positions rather contemplation, because he considered the process of self-improvement to be the most valuable. Fortunately, numerous calls to the KGB since 1951 did not end in imprisonment for P. Bedzir. «If Stalin had lived, I would have been imprisoned a long time ago. Probably they needed me. Probably, this is how some connections and contacts could be observed», - explained artist this fact $[1,27]$. These assumptions of the artist explain his demand at exhibitions and inclusion in the leadership of the youth commission, which according to the decision of the III All-Union Congress of Artists was organized in the regional union in March 1971 [8, 2]. Soviet oxymoron: an informal artist in a commission which aimed at open control over the work of young artists - a vivid illustration of the programmed ideological control of any free thought in creative circles.

Radical positions of P. Bedzir, E. Kremnytska and F. Seman were critical of the norms, giving priority to their own position in contrast to the generally accepted stencil canons $[19,4]$. Unaffiliated with socialist-realist issues, their activity was an alternative to the official one and became a bright manifestation of nonconformism in Transcarpathian painting. The systemic nature of official art was contrasted with chaos, incompleteness and spontaneity, which is confirmed by the stylistics of the works, focused on the waves, that were banned in the USSR (abstractionism, surrealism, op-art, Tashism). Against the background of ceremonial and official art, attention in the works of these artists was focused on personal or individual themes. The search for something new was conducted in the direction of finding the foundations of creativity, restoring the lost aesthetic and philosophical basis.

P. Bedzir's nonconformism of philosophical and artistic considerations was based on an open distrust of the Soviet system's values and skepticism about rationalism. Changes in the principles of plastic modification of forms and colors based on appeals to the achievements of late artistic trends of the XX century, the first forms of ethno-culture, folk art and ornament of Transcarpathia [3] became the aesthetic platform for E. Kremnytska and F. Seman. This movement in Ukrainian painting was a continuation of the ideas of the sixties, which in their works synthesized two directions: the emergence of new complex formal structures 
of education and national, which freed painting from the canons of socialist realism towards national self-identification.

Inherent in the formation of artistic nonconformism was the involvement of the traditions of folk painting, return to their own mentality, romanticization of the spirit, the search for a new visual structure for thematic painting [16, 23]. If in the 1960s the «strict style» became the first modification of social realism, a kind of reaction of artists to its improvement, the nonconformists filled painting with an individual worldview that had been in an amorphous state for so long.

An interesting manifestation of nonconformism in the artistic environment were «samvydavy» [11, 212-271; 15], which were shared in a limited space on the principle of personal trust, but were published regardless of geographical locations or state borders and frontiers [18]. They included literary and artistic works, «albums» of photo reproductions or disgraced works of artists, dissident texts of ideological content, audio recordings of individual performers, groups or collectives. The circulation of this cultural product was closely monitored by the state security agencies, withdrawn from circulation, often with the active assistance of secret agents (usually failed), but also of professional «honest» writers, artists, journalists and more. However, a large proportion remained «on hand», even when preventive talks were held with the authors, freedom of creativity and communication were restricted, moral and ethical «sins» or more radical measures were suppressed: involvement in investigative and judicial proceedings as witnesses and accomplices, dismissal from office, work, etc.

Interpersonal contacts of representatives of artistic, technical, educational, official, etc. intelligentsia also went beyond regional or state borders, which is natural for the Ukrainian interstate contiguity, and often had a family character, This therefore contributed to the relative alignment of nonconformist sentiments, ideas, beliefs in wider spaces. This can be clearly seen, in particular, on the peculiarities of penetration into Transcarpathia of foreign literary and artistic publications, periodicals, professional lectures and the same foreign «samvydav», respectively, from Poland, Czechoslovakia, Hungary, Yugoslavia, Italy, France, Germany, the Baltic countries, etc. $[4 ; 18]$. There was a lot of Ukrainian dissident material on the pages of «legal» official foreign publications, which was strictly monitored and forbidden within the USSR. Interestingly, these publications often had quite loyal cover, such as the implementation of interstate cultural exchange programs 
in the context of government visits or the celebration of historical calendar dates (Days of Cultures, anniversaries of the October Revolution, international scientific conferences, etc.). That is how literary and artistic publications, reviews, critiques, articles written by and about a special group of authors appeared in the countries of The Commonwealth. Those authors were taken out of official context, often repressed or physically destroyed in Ukraine and in the USSR in general. And these, in particular, were persons, events and phenomena of the Shot Renaissance, the sixties, political dissent.

The significant place in the spread of nonconformist-dissident sentiments and beliefs in Transcarpathia deserves the systematic functioning in the near abroad of the Scientific Collection of the Museum of Ukrainian Culture in Svydnyk (NZ MUK) and literary and artistic magazine «Duklia». Art history materials that deviated significantly from the official doctrine on this side of the border, were published on their pages $[4 ; 5 ; 14]$. The volumes «NZ MUK in Svydnyk» and the numbers «Duklia» in different ways came to Transcarpathia and beyond the watershed and acted as a powerful intellectual leader in the generally ideologically suppressed world of science and art in Ukraine. Scientific, in particular, art publications of Ivan Matsynskyi, Orest Zilynskyi, Mykola Mushynka, Stepan Hapak, Stepan Pap, Olena Rudlovchak, Mykhailo Molnar, Mariia Maier, etc., not only broadened the worldview horizons but also fundamentally affected the formation of basic scientific positions of artistic and scientific intelligentsia $[4 ; 5 ; 14 ; 18]$. In fact, among nonconformist dissidents, some topics were updated and often acted as a kind of indicator or marker of involvement, such as, for example, Bohdan-Ihor Antonych or Andy Vorhol. These two poles, which grew up on a specific Lemko background, contained a great «destructive» potential of a wide range of social realism as a creative method and did not allow for «organic» adaptation to the Soviet way of thinking and articulation [4].

It is a little-known fact that the Ukrainian diaspora in the United States and Canada were involved in the formation of nonconformist sentiments and the inculcation of «other» ideological and aesthetic tastes and evaluative categories. Indicative in this regard is, in particular, the organization and holding of a festive meeting in the Ukrainian House in New York on March 19, 1977 with the following program: 1) On the 38th anniversary of the independence of Carpathian Ukraine; 2) Yosyp Bokshai - Ukrainian patriot and Ukrainian painter; 3) Demonstration of 
Bokshai's paintings. On the one hand, the events of Carpathian Ukraine in the USSR were tabooed, discredited and had a clear negative, «hostile», «nationalist» definition. On the other hand, the figure of Yosyp Bokshai was canonized as the pinnacle of socialist culture at the national level. In the nonconformist environment, the indisputable authority of Y. Bokshai was based, in particular, on his genre paintings of a sacred nature, numerous church mural, oral legends about the participation in national and state-building competitions of the interwar period, material artifacts from private sets and collections.

Let's also mention the spread of the nonconformist worldview through tourist and recreational, traveling-educational methods. They included interstate exchange of performances of creative associations, unions, tourist groups, bilateral family and household visits. For example, the annual Festival of Ukrainian Culture in Svydnyk, which gathered hundreds and hundreds of participants, created favorable conditions for extremely important interpersonal contacts, even despite close control by the state security agencies of both countries. The same can be said about an open-air practice, especially interstate and international, which, as well, has not been studied yet. And this was not the last micro-community for the formation of nonconformism [4].

Here it must be stated about the nonconformism of the 70s and 80s among the creative intelligentsia of the Hungarians in Transcarpathia, which had a clear organizational structure and created a very serious problem for the state security agencies due to ideological interest in these processes by neighboring Hungary. Activities of literary and artistic associations «Forrash», «Alfeld», literary studio of Yozhef Attyla, their contacts with the Ukrainian community of Transcarpathia (and they occurred), etc., today are almost unexplored and not studied [17].

There also should be mentioned official structures of the Soviet ideological machine, which at the same time were a micro-communities for formation and spread of nonconformist-dissident sentiments and beliefs, as the state publishing house «Karpaty», which served Transcarpathia, Ivano-Frankivsk, Chernivtsi region and worked closely with Slovak and Hungarian book publishers, Transcarpathian Music and Drama Theater, Uzhhorod National University, regional philharmonic, regional museum, creative unions of artists and writers, who, despite the dense infiltration of paid, full-time informants and «honest» 
secret workers, failed to achieve a total cleansing of the creative space under the Carpathian sky from «hostile ideology» and «criminal activity».

Conclusions. Thus, the artistic underground environment of Transcarpathia is a definite and courageous response of creative personalities to the reactionary social phenomena of the $1960 \mathrm{~s}-1980 \mathrm{~s}$, and the general analysis of alternative painting genre of Transcarpathia in the 1970s-1980s reveals a wide range of influences both of world art trends and features of ethno-culture of Transcarpathia. The works of F. Manailo, E. Kremnytska, P. Bedzir, F. Seman, Y. Cherni were distinguished by their own technique of creating compositions, the search for new methods of shaping, which rather corresponded to the state of enlightenment. Unlike artistic manifestations in the spirit of socialist realism, such creative experiments were associated with social freedom. Such processes of creative digression significantly influenced the formation of a new paradigm that emerged in the early 1990s.

\section{REFERENCES}

1. Ghavrosh O. (2006) Zakarpatsjke stolittja : 20 interv'ju [Transcarpathian century : 20 Interview]. Uzhghorod: Myst. Linija. (in Ukrainian).

2. Ghavrosh O. (2013) Pobutovyj zhyvopys Zakarpattja povojennogho desjatylittja: osoblyvosti transformaciji zhanru v umovakh socrealizmu [Genre painting of Transcarpathia of the postwar decade: features of genre transformation in the conditions of social realism]. Visnyk KhDADM: zb. nauk. pr. / za red. Danylenka V. Ja. Kharkiv : KhDADM, pp. 70-74. (in Ukrainian).

3. Vysheslavsjkyj Gh. A., Sydor-Ghibelinda O. V. (2010) Terminologhija suchasnogho mystectva. Oznachennja, neologhizmy, zharghonizmy suchasnogho vizualjnogho mystectva Ukrajiny [Terminology of modern art. Meaning, neologism, jargon of the modern visual mystery of Ukraine]. Paryzh : Kyjiv. (in Ukrainian).

4. Rebryk I. (ed.) Vidnajdennja Prjashivsjkoji Rusi-Ukrajiny [Discovery of Presov Rus'-Ukraine]. 1 / uporjad. ta pidgh. tekstiv I. Rebryka ; pisljamova prof. M. Mushynky ; red. rada: prof. L. Belej ta in. Uzhghorod : Grazhda. (in Ukrainian).

5. Ghapak S. Obrazotvorche mystectvo na Zakarpatti i Prjashivshhyni pid chas buvshoji Chekhoslovachchyny [Fine arts in Transcarpathia and Prešov during the former Czechoslovakia]. Duklja, 1968, no. 3, pp. 211-216. (in Ukrainian). 
Oksana Havrosh, Nataliia Rebryk. Artistic nonconformism of Transcarpathia of 1960-1980...

6. Gholubecj O. (2011) Ukrajinsjke mystectvo 20 st.: problemy nacionaljnoji identyfikaciji [Ukrainian art of the twentieth century: problems of national identification]. Artanija, vol. 25, no. 4, pp. 16-24. (in Ukrainian).

7. State Archives of the Transcarpathian region. Otchetno-vybornoe sobranie Zakarpatskoy organizatsii Soyuza khudozhnikov USSR ot 1968 - 24.11.1972. [Reporting and election meeting of the Transcarpathian organization of the Union of Artists of the Ukrainian SSR 1968 - November 24, 1972]. F. R-1544. Op. 1. Spr. 230. 122 ark. (in Russian).

8. State Archives of the Transcarpathian region. Teksty dokladov za 1973 god [Texts of reports for 1973]. F. R-1544. Op. 1. Spr. 238. 32 ark. (in Russian).

9. State Archives of the Transcarpathian region. Protokoly zasedaniya pravleniya Soyuza khudozhnikov Zakarpatskoy oblasti (3 yanvarya 1958 - 19 noyabrya 1958) [Protocoles of the meeting of the Board of the Union of Artists of the Transcarpathian region (January 3, 1958 - November 19, 1958)]. F. R-1544. Spr. 85. 28 ark. (in Russian).

10. Zakarpatsjka poezija XX st. : antologhija (2003) [Transcarpathian poetry of XX st. : anthology] / peredm. V. Ghusti. Uzhghorod : Zakarpattja. (in Ukrainian).

11. Kreminj D. (2021) Z dniv shalenykh. Knygha rannjoji liryky ta virshiv «zakarpatsjkogho cyklu» [From crazy days. Book of early lyrics and poems of the «Transcarpathian cycle»] / peredm. T. Kreminj, spivuporjadnyky: T. Kreminj, I. Rebryk, N. Rebryk. Mykolajiv : Ilion. (in Ukrainian).

12. Lyst Volodymyra Kachurovsjkogho do Avghustyna Shtefana vid 9 bereznja (1977) [Letter of Vladimir Kachurovsky to Augustin Stefan dated March 9] Pryvatna zbirka N. Rebryk. (in Ukrainian).

13. Ostrovskiy G. (1966) Khudozhniki Zakarpatya [Artists of Transcarpathia]. Iskusstvo, no. 5, pp. 20-25. (in Russian).

14. Pap S. (1979) Ikony j ikonopysannja na Zakarpatti [Icons and icon painting in Transcarpathia]. Zapysky ChSVV, vol. XIV (XX); Rym, 1992. Pp. 123-151. (in Ukrainian).

15. Rebryk N. J. Mystectvo samostverdzhennja u slovi: vid andegraundu do klasyky. Oljvijsjkyj vertep Dmytra Kremenja [The art of self-affirmation in the word: from the underground to the classics. Dmitry Kremen's Olvia Nativity Scene]. Visnyk Zakarpatsjkogho khudozhnjogho instytutu, vol. 5 : Erdelivsjki 
chytannja. Uzhghorod : Zakarpatsjkyj khudozhnij instytut, 2014, pp. 34-37. (in Ukrainian).

16. Smyrna L. (2007) Ukrajinsjkyj mystecjkyj nonkonformizm: istorychnyj i svitoghljadnyj vymir. [Ukrainian artistic nonconformism: historical and ideological dimension]. Narysy z istoriji obrazotvorchogho mystectva Ukrajiny $X X$ st. [Essays on the History of Art of Ukraine of the XX century] : v $2 \mathrm{kn}$. Kn. 2 / In-t problem suchasnogho mystectva Akademiji mystectv Ukrajiny. Kyjiv : Intertekhnologhija, pp. 5-77. (in Ukrainian).

17. Spravka o kompleksnom ispolzovanii agenta «Miklosh» [Information on the integrated use of the agent «Miklosh»] / Upr. KGB USSR. Vkh. №3623-30/8-82 ot 30 agusta 1982 g. : Kopiya. Pryvatna zbirka N. Rebryk. (in Russian).

18. Mushynka O. (ed.) U vsjakogho svoja dolja... Rozmova Jaroslava Shurkaly z Mykoloju Mushynkoju [Everyone has their own destiny... Conversation of Yaroslav Shurkala with Mykola Mushynka]. Prjashiv : Centr antropologhichnykh doslidzhenj. (in Ukrainian).

19. Havrosh O. (2014). Ideas nonconformity in genre paiting of Elizabeth Kremnytska. The First International conference on development of history of art and cultorology in Eurasia. Proceedings of the Conference (November 3, 2014). «East West» Association for Advanced Studies and Higher Education GmbH, 3-7. 